\title{
Effects of grants from EU funds on business performance of non-financial corporations in Croatia
}

DOMAGOJ ŠELEBAJ, MSc ${ }^{*}$

MATEJ BULE, MSc*

Article $^{* *}$

JEL: C14, D22, H81

https://doi.org/10.3326/pse.45.2.1

\footnotetext{
"All views presented in this paper are the authors' own and do not necessarily reflect the official position of the Croatian National Bank. The authors would like to thank two anonymous reviewers and colleagues from the Croatian National Bank for their useful suggestions.

${ }^{* *}$ Received: June 1, 2020

Accepted: February 10, 2021
}

The article was submitted for the 2020 annual award of the Prof. Dr. Marijan Hanžeković Prize.

\section{Domagoj ŠELEBAJ}

Croatian National Bank, Trg hrvatskih velikana 3, 10000 Zagreb, Croatia

e-mail: domagoj.selebaj@hnb.hr

ORCiD: 0000-0002-4639-2973

Matej BULE

Croatian National Bank, Trg hrvatskih velikana 3, 10000 Zagreb, Croatia

e-mail: matej.bule@hnb.hr

ORCiD: 0000-0002-8789-0805 


\section{Abstract}

This paper quantifies the impact of grants from EU funds on non-financial corporations performance in Croatia. For the purposes of the research, three different data sources were used, which were merged into a single enterprise level database. Enterprises for the control group were selected using propensity score matching method, while the quantifications of effects in the years after receiving the support were estimated using difference in differences method. Also, the doseresponse relationship between the relative size of the received grant and the level of impact on performance indicators was assessed. The research showed that the use of EU funds has a strong and positive effect on the observed indicators, such as employment, operating income, labour productivity or total factor productivity and capital intensity. At the same time, the level of impact significantly depends on the relative size of grant received from $E U$ funds.

Keywords: EU funds, propensity score matching, difference in differences

\section{INTRODUCTION}

Apart from access to the common European market, one of the most important economic benefits arising from Croatia's membership in the European Union (EU) is the eligibility to use EU funds. Since Croatia, just like the majority of new member states, is classified as an underdeveloped country, the amount of funds it received is substantially larger than the amounts it pays into the shared European budget. In 2019 alone, end beneficiaries received EUR 1.9 billion, or $3.6 \%$ of Croatia's GDP, from EU funds on various grounds, while Croatia's contribution to the shared budget amounted to around EUR 0.5 billion, or $1.0 \%$ of GDP (authors' calculation based on data by the Ministry of Finance and the Croatian National Bank). It should be pointed out that Croatia is yet to enter the final stage of the utilization of funds from the 2014-2020 budgetary period, in which the payments to end beneficiaries for contracted projects are expected to reach their peak.

However, support in such large amounts of grants is bound to have certain direct and indirect effects, which are harder to measure than is the case with direct financial benefit. Apart from the problem of data accessibility (especially at the microlevel), an additional burden is the fact that grants from EU funds are used to finance a wide variety of various social areas and economic sectors with divergent objectives and potential effects - from family farms or projects with a social element aimed at the wider population or non-profit associations all the way up to large infrastructural projects managed by the state or local government units or projects by non-financial corporations.

To the authors' best knowledge, this is the first-ever paper to quantify the effects of grants from EU funds on end beneficiaries in Croatia or, more specifically, on the business performance and features of Croatian non-financial corporations. As such, it represents a giant leap in the analyses conducted thus far and substantially contributes to the national professional literature on the topic of support from EU 
funds. Apart from quantifying the effects of the grant, the paper also elaborates on additional research questions such as the probability of obtaining EU funding and the ratio between the size of the support received and its impact level (doseresponse). Since this ratio between the size of the received grant and the level of its impact has practically not been researched before, this piece of research also provides a substantial scientific contribution.

Finally, the conclusions arising from the results of this research can assist the competent bodies when adopting policy decisions regarding the allocation of available grants from EU funds. Namely, non-financial corporations represent a section of the national economy which is a significant beneficiary of EU funds; their case would make valuable testing ground for the assumption that the use of EU grants might have a positive effect on the performance of many enterprises, thus contributing to the competitiveness of the national economy, or at least partially alleviate the consequences of certain structural deficiencies of this sector, such as high indebtedness or low productivity rates (cf. Martinis and Ljubaj, 2017; Gelo and Družić, 2015).

Even though the results of the analysis conducted show that these grants do have a significant positive effect on the performance of corporate beneficiaries, several additional recommendations for economic policy management can be highlighted. For instance, it is important to highlight that the age of an enterprise and the number of its employees are some of the key estimators of the probability of obtaining support. Such findings are far from unexpected, but more effort should be put in making funds more accessible to younger enterprises or start-ups, since access to funding is one of the most common problems faced by such enterprises. In addition, it has been shown that, regardless of the fact that the support comes in the form of a grant, the use of funds has a negative effect on relative profitability of business, which poses a challenge for market profitability of the funded projects and leaves room for moral hazard. For this reason, greater focus should be placed on profitability issues during the grant allocation procedure. One of the more important markers of efficiency is the relative size of the support, hence this factor should also be taken into account during the allocation procedure.

\section{OVERVIEW OF RELEVANT LITERATURE AND CONTRIBUTION OF RESEARCH}

The issue of potential effects of cohesion policy is one that frequently comes up in applied econometric research. Darvas et al. (2019) identified over 1,000 different pieces of research dealing with various aspects of cohesion policy such as efficacy, convergence, inequality, management and many others. Since the main objective of cohesion policy is reducing the development gap between individual regions, or convergence of underdeveloped regions, as well as stimulating general economic growth, literature is dominated by the issue of efficacy of EU's cohesion policy for achieving these objectives (for an overview of previous research, see e.g., Hagen and Mohl, 2009; Marzinotto, 2012; Pienkowski and Berkowitz, 
2015; Crescenzi and Giua, 2017). However, the results are far from uniform. Depending on the sample size, time period, conceptual and methodological framework, the majority of papers unveil a positive effect of cohesion policy on regional growth and convergence (e.g., Cappelen et al., 2003; Esposti and Bussoletti, 2008; Ferrara et al., 2016). Despite finding positive effects, some pieces of research nevertheless challenge its efficacy (Dall'Erba and Le Gallo, 2008; Bouayad-Agha et al., 2011; Becker et al., 2013), i.e., they argue that cohesion policy is only tentatively efficient in meeting its objectives (e.g., Ederveen et al., 2002; Ederveen et al., 2006; Rodriguez-Pose and Fratesi, 2004). On the other hand, some pieces of research also claim that cohesion policy has a negative effect on economic growth (Fagerberg and Verspagen, 1996; Breidenbach et al., 2016).

The majority of conducted research, including the ones listed above, use individual countries or NUTS regions as the observation unit. This approach is subject to criticism from various sides, the most important being the issue of endogeneity (Hagen and Mohl, 2009). Endogeneity arises due to the fact that an individual region's ability to qualify for grants from cohesion funds is defined by its economic size, meaning that the per capita GDP of regions that are eligible for obtaining grants from cohesion funds is substantially lower than the EU average. However, regions that were initially underdeveloped may experience sharper growth due to convergence only, regardless of the grants obtained from the Cohesion Fund (Cappelen et al., 2003).

Research looking at the efficacy of cohesion policy on an aggregate level is countered by literature examining the potential effects of EU funds on the performance of enterprises that are the beneficiaries of grants through cohesion policy. Due to lack of data, microeconomic research is still very limited, although such an approach would eliminate the endogeneity issue that is inherent to aggregate research. Only a few papers assessed the potential effects of grants from cohesion funds on a limited set of enterprise performance indicators, primarily the trends in the number of employees and enterprise productivity, expressed either as total factor productivity (TFP) or labour productivity.

The majority of research conducted at enterprise level used a quasi-experimental approach of propensity score matching and the difference in differences method and discovered positive effects of obtaining a grant from cohesion funds on trends in employment numbers, revenue and/or productivity (see Moral Arce and Paniagua San Martín, 2016; Fattorini et al., 2018; Hartsenko and Sauga, 2013). Benkovskis et al. (2018) used microdata from Latvian enterprises to examine the effect of grants from the European Regional Development Fund on a much wider set of performance indicators. In their research, they used the propensity score matching technique, which has shown that obtaining the grant led to an increase in the enterprises' capital intensity as well as employee numbers not long after receiving the support, while the effect on the productivity trend was also positive but became evident only three years into the grant. Apart from this, the effects of the grant 
were not homogeneous for all enterprises; enterprises that were slightly larger, but also less productive, before receiving the grant benefited more from the grant.

Bachtrogler and Hammer (2018) examined the effects of the use of EU grants from the 2007-2013 financial perspective on the performance of enterprises in 25 member states. The results of their analysis, derived through the propensity score matching method, have shown that corporate beneficiaries of grants in all countries under consideration recorded a substantial increase in employee numbers, revenue and fixed asset value, while on the other hand, evidence showing an increase in total factor productivity has been limited. The results presented in other papers are far from unambiguous. In one of the first papers that attempted to quantify the use of EU grants against the performance of non-financial corporations, Zwaan and Merlevede (2013) used grant beneficiaries from the processing industry in all EU member states in the 2000-2006 period as a case study and concluded that obtaining the grant did not affect the enterprises' employment numbers and productivity.

All pieces of research referred to above failed to take into account the effect of the magnitude of the received support from EU funds on the trend in selected performance indicators. Rather, they merely considered the fact that the enterprise became a beneficiary of the grant. Apart from being one of the first attempts to quantify the obtained grants from EU funds against performance indicators of enterprises in general, the main contribution of this paper is that it is, to the authors' best knowledge, the first paper to assess the effect of the size of the received support from EU funds on business performance indicators of enterprises. In addition, this research complements previous national literature studying EU funds in Croatia from various aspects, literature which is, due to Croatia's late EU accession, still quite modest. Areas and topics covered so far include the impact of EU funding on national research capacities, challenges of public procurement for EUfunded projects, absorption capacities for EU funds, the effect of cohesion policy on regional development in Croatia, the role of EU funds in the development of rural tourism, aid received from the European budget by local and regional selfgovernment units or the question of whether SMEs are familiar with funding possibilities from EU funds (see Šostar and Marukić, 2017; Poljičak, 2017; Kotarski, 2016; Maleković et al., 2018; Medić et al., 2017; Ott et al., 2018; Sikirić et al., 2015; Visković and Udovičić, 2017; Bartoluci et al., 2018; Kersan Škabić and Tijanić, 2017). In addition, this research also complements previous literature dealing with the effect of public support provided to non-financial corporations, whose source of funding is not the shared European budget but rather national budget or budgets of local and regional self-government units (see Srhoj et al., 2018). Public support to private non-financial corporations funded by taxpayers' money is an especially sensitive social issue because of questionable efficiency of such programmes and the issue of social justice. For this reason, any research on this topic can be highly relevant. 
This research uses three different data sources at enterprise level with different time series durations, which have been aligned and connected into a unique database covering the period 2012-2018, the first database of its kind. All data regarding the allocation of funds to end beneficiaries have been retrieved from the database maintained by the Ministry of Finance, which keeps track of all payments to beneficiaries of EU support on a monthly basis. This database also includes a code of the fund from which the grant was allocated. Data on monthly payments for individual enterprises have been aggregated at the annual level and connected to the database of annual financial statements maintained by the Financial Agency (Fina). Fina's database of annual financial statements contains detailed information derived from the enterprises' closing balance sheets, profit and loss accounts but also other non-financial features of enterprises conducting business in Croatia, such as the number of employees, head office, ownership structure based on the proprietor's residential status, etc. The third database used in the present research is the Court Register of Businesses Operators in Croatia, which contains data on the year each enterprise was established. This database was used to ascertain the enterprises' age.

By merging three different data sources, we created a new, unique database with 774,449 observations for the 2012-2018 period. Our sample identified 1,921 unique enterprises that became a beneficiary of a grant from EU funds in the observation period. However, further analysis required major adjustments. The number of corporate beneficiaries includes a certain number of public enterprises and entities that are registered as an enterprise but are owned by the state or local and regional self-government units. Such enterprises were excluded from the analysis due to having drastically different business objectives, which might ultimately affect the results of the analysis. This reduced the number of beneficiaries to 1,685 enterprises. We also excluded all enterprises that did not have a single employee in the observation period or failed to achieve positive value of their operating income, leaving us with 1,643 corporate beneficiaries.

Since the main objective of the analysis was to assess the medium-term effects of the grants on corporate beneficiaries' business performance and features, which for the purpose of the research implies that performance data is available for the period of at least two years after initially receiving the grant, we also needed to exclude enterprises that obtained their first grant in 2017 or 2018 from the main part of the analysis. The time distance to make an impact assessment for such enterprises has not been long enough, since data on their performance in 2019 and 2020 is not available. This had a major impact on the number of corporate beneficiaries under observation. Having conducted the process of database cleaning and exclusions referred to above, we were left with 476,685 observations for the empirical analysis, collected from 227 enterprises that obtained support for co-funding their projects from EU funds. Appendix 3 shows that the enterprises remaining in the sample after all the adjustments are slightly older, more productive, with more capital intensity, 
more indebtedness, more export intensity and more employees than the overall sample of enterprises that received grants from EU funds.

The paper considered twelve indicators in total, some of which have been directly taken from primary sources since some values, such as operating income, fixed assets values, values of exported and imported goods and services, are, in accordance with accounting standards, a component of the enterprises' profit and loss account, final balance sheet and other financial statements. All other indicators have been derived from data sources referred to above, using the standard calculation method applied in previous professional literature that is based on data processing at enterprise level. For instance, the employment indicator has been calculated on the basis of completed hours of labour in order to account for the fact that some enterprises provide for overtime hours, while some enterprises have part-time employees, which can skew the true representation of the employment rates at individual enterprises. On the other hand, by analysing only operating income rather than total revenues, we avoid the possibility of quantifications being affected by one-off exceptional revenue, including the support from EU funds itself.

The calculation method for all other indicators (labour productivity, added value, capital and export intensity, indebtedness, profitability and enterprise age) is provided in appendix 1. In addition, appendix 2 provides a detailed explanation of the calculation method for total factor productivity based on the Cobb-Douglas production function. It is also important to note that some of the nominal variables have been deflated to exclude the effect of price changes, which means that only their real changes were taken into account (the deflators used are also described in appendix 1). In conclusion, all variables and indicators used, with the exception of enterprise age, are observed as their logarithmic transformations.

\section{METHODOLOGY}

\subsection{ECONOMETRIC MODELS AND TECHNIQUES USED}

The empirical analysis used has widely been applied in previous similar papers the so-called average treatment effect on treated method (ATT). The causal treatment effect, in this case receiving support from EU funds, can be defined as the difference between a potential outcome in an enterprise's observable performance upon receiving support and a potential outcome that would have occurred had the support not been received, or, in mathematical terms:

$$
A T T=E\left[\Delta Y_{i, t+s}^{1} \mid E U=1\right]-E\left[\Delta Y_{i, t+s}^{0} \mid E U=1\right]
$$

The first term in the equation $E\left[\Delta Y_{i, t+s}^{1} \mid E U=1\right]$ denotes a change in the group of indicators under observation for enterprises that received support in the period $t$, i.e., between one year prior to receiving the grant $(t-1)$ and $t+s$ years after receiving the grant. The second term in the equation $E\left[\Delta Y_{i, t+s}^{0} \mid E U=1\right]$ marks a hypothetical growth rate of the indicators under scrutiny for the same group of enterprises which would have occurred had the support not been received. Since the 
defined outcomes for the group populated by corporate beneficiaries are not observable in hypothetical conditions (i.e., not having received support), the crucial evaluation problem is to find a group of enterprises for which such trends can be approximated to a high extent. In other words, in order to estimate the average treatment effect on treated (ATT), we should find a control group of enterprises (those that have not received any grant from EU funds), whose initial features are quite similar to the group of enterprises that have received grants.

The first step entails calculating the probability of obtaining a grant from EU funds as a function of observable enterprise features in the period prior to receiving support - features which are considered to affect the probability of receiving the grant. When observing the initial features prior to receiving the treatment itself, if there is no significant effect of non-measurable or unobservable features, the selection bias is reduced, i.e., it is assessed as statistically non-significant. The probability above is referred to as propensity score and is calculated through the following probit regression (Rosenbaum and Rubin, 1983):

$$
P\left(E U_{i, t}=1\right)=F\left(X_{i, t-1}, \text { Control }_{i, t}\right)
$$

where $E U_{i, t}$ denotes an indicator variable in case enterprise $i$ is a beneficiary of grant from EU funds, $F$ indicates the standard normal distribution function, while $X_{i, t-1}$ designates the vector of performance indicators and other features under scrutiny within one year prior to receiving the EU grant. It encompasses the productivity indicators (total factor productivity and labour productivity), enterprise age, employee numbers, capital and export intensity and the indebtedness coefficient. In addition, the vector Control $_{i, t}$ also expands the estimation with standard control variables for the year and the activity that the enterprise under observation conducts (to the second digit level of National Classification of Activities - NACE).

The estimated probability of receiving support from EU funds is used in the second step for enterprise matching. The probability of starting a project that is cofinanced from EU funds for enterprise $i$ in sector $k$ in period $t$ is labelled $p_{i, k, t}$. One or several control enterprises $j$ with the smallest absolute difference in the estimated propensity score is then matched with the enterprise that received the treatment by using the nearest neighbour method.

$$
\left|p_{i, k, t}-p_{j, k, t}\right|=\underset{j \in\left\{E U_{i, k, t}=0\right\}}{\min }\left(\left|p_{i, k, t}-p_{j, k, t}\right|\right)
$$

In order to ensure higher comparability of business results and enterprise features, an additional condition was introduced - that all matched enterprises should belong to the same NACE class and the same year, as per Bachtrogler and Hammer (2018) and Benkovskis (2018). To ensure robustness and higher reliability of obtained results, matching is done in such a manner that each enterprise that received the treatment is matched with 1, 2, 5 and 10 most similar enterprises, which then form the control group. In alternative model specifications, the matching is conducted by 
using a pre-defined caliper value, i.e., maximum tolerated difference in the estimated propensity score between the treated enterprises and the control group enterprises. If no control enterprise is located within the defined caliper, the matching is deemed as not having been conducted and such enterprises from the treated group are excluded from further analysis. In addition, matching is conducted without replacement; considering a large number of potential control enterprises, this prevents each control enterprise from being matched with more than one treated enterprise. The quality of the matching exercise is usually assessed by comparing the mean values of the variables under observation before and after matching. If the matching leads to no statistically significant difference, the balance condition has been met and the exposure to grant allocation can be considered random.

Having estimated the probability of receiving treatment and having matched enterprises that obtained grants from EU funds with enterprises in the control group, the final step serves to calculate the average effect of the treatment on the treated enterprise by applying the standard difference in differences method. The first step in the difference in differences method is to calculate the growth rates of the variable under observation for both enterprise groups. The average difference between these growth rates is calculated as:

$$
A T T^{D I D}=\frac{1}{N_{T}} \sum_{i \in T}\left[\Delta Y_{i, t+s}^{T}-\sum_{j \in C(i)} \omega_{i, j} \Delta Y_{j, t+s}^{C}\right]
$$

where $N_{T}$ indicates the number of enterprises that received grants from EU funds, $0<\omega_{i, j}<1$ is the weight for the control group of enterprises generated by the matching algorithm, $s$ indicates the number of years for which the change in performance indicators or features is observed, starting from $t-1$ (one year prior to receiving support) until $t+s$ after receiving support, whereby $s \in\{0,1,2\}$. If the difference in growth rates of the observable performance variables or enterprise features turns out to be positive and statistically significant, we can say that the effect of the treatment (co-financing through grants from EU funds) had a positive effect on the observable performance indicators of the enterprise in the period after receiving the treatment.

Finally, apart from providing an answer to the question which features of enterprises increase the probability of obtaining grants from EU funds and whether such a benefit enhances the growth of observable performance indicators, the third objective of the present paper is to understand whether there is a difference in the causal effects of co-financing considering the relative size of the grant. A more appropriate methodology for answering this question is the propensity score binary effect generalization method for a treatment variable that is considered a continuous variable (Hirano and Imbens, 2005). By applying the generalised propensity score, we can estimate the dose-response function and determine whether the causal effects of the received support on the change in the variables under observation vary depending on the different relative size of the allocated grant from EU funds. Only a small number of previous applied research used such a 
method at enterprise level, while they mostly applied it for exploring the connection between export intensity and productivity growth (Fryges and Wagner, 2008) or the intensity of different support types on the growth of indicators under observation such as employment rate, revenue or productivity (see e.g., Cerulli and Poti, 2014; Dai and Cheng, 2015; Dai et al., 2017; Becker et al., 2019). To the authors' best knowledge, this is the first attempt of using the above method for assessing the effects of co-financing through grants from EU funds.

The methodology referred to above is usually implemented in three steps. The first step entails an assessment of the generalised propensity score on a sample of the treated enterprises, based on the relative amount of the grants received from EU funds. The treatment variable under scrutiny, $T_{i}$, indicates the annual amount of grants received from EU funds expressed as a share in the enterprise's operating income in the period of one year prior to receiving the grant $(t-1)$. Based on Hirano and Imbens (2005), we assume normal distribution of the treatment variable considering the vector of selected control variables:

$$
T_{i} \mid X_{i} \sim N\left(\beta_{0}+X_{i} \beta_{1}, \sigma^{2}\right)
$$

whereby $X_{i}$ is the same vector of the control variables used in the binary propensity score estimation. Since the empirical distribution of the relative amount of the grants received fails to meet the normality assumption, the analysis used its logarithmic transformation. The generalised propensity score is then estimated by applying the least squares method:

$$
\hat{R}_{i}=\frac{1}{\sqrt{2 \pi \hat{\sigma}^{2}}} \exp \left(-\frac{1}{2 \hat{\sigma}^{2}}\left(T_{i}-\hat{\beta}_{0}-X_{i} \hat{\beta}_{1}\right)^{2}\right)
$$

The second step entails an estimation of the conditional outcome expectation. Concretely, this refers to the average growth rate of the variables under scrutiny one year and two years after receiving the grant, as a function of the observable treatment levels and the estimated generalised propensity score, by using their squared approximation:

$$
E\left[\Delta Y_{i} \mid T_{i}, R_{i}\right]=\alpha_{0}+\alpha_{1} T_{i}+\alpha_{2} T_{i}^{2}+\alpha_{3} R_{i}+\alpha_{4} R_{i}^{2}+\alpha_{5} T_{i} R_{i}
$$

By using the assessed parameters from equation (7), the final step entails an estimation of the dose-response function, i.e., the average potential outcome of the vector of the variables under observation depending on the various relative levels of the received treatment $t$ :

$$
\hat{E}[\Delta Y(t)]=\frac{1}{N} \sum_{i=1}^{N}\left(\hat{\alpha}_{0}+\hat{\alpha}_{1} t+\hat{\alpha}_{2} t^{2}+\hat{\alpha}_{3} \hat{R}\left(t, X_{i}\right)+\hat{\alpha}_{4} \hat{R}\left(t, X_{i}\right)^{2}+\hat{\alpha}_{5} t \hat{R}\left(t, X_{i}\right)\right)
$$

whereby $N$ is the total sample size. Since dose-response is a non-linear function of the relative size of treatment $t$, one of the main advantages of the approach used is the fact that no restrictions are assumed in advance regarding the connection 
between the continuous treatment intensity and outcome (Fryges and Wagner, 2008). The dose-response function is estimated for each distribution percentile at treatment $t$ level on the $[5,35]$ interval, which empirically contains relative amounts of the received grants. Since such an approach, similar to the binary propensity score, takes into account differences in features before receiving support, the estimated differences in average outcomes for two different treatment intensities can be interpreted as causal effects of the differences in intensity of support received from EU funds.

\subsection{SELECTION OF VARIABLES FOR PROBIT MODEL}

The selection of variables for the probit model mostly reflects key features and previous knowledge regarding the utilization of grants from EU funds by nonfinancial corporations. It is a known fact that a substantial amount of funds made available for funding projects of non-financial corporations from ESI funds is aimed at stimulating capital investment in production capacities. For this reason, beneficiaries of EU grants are more likely to come from capital intensive sectors. For this reason, sector of economic activity is a control variable in the model, while the enterprise's capital intensity level has been included as one of the independent variables. In addition, since the participation in a public tender for the award of grants from EU funds and drafting the tender documentation requires substantial administrative capacities, we can assume that the grant beneficiaries are slightly older enterprises with a higher number of employees and larger administrative capacities. These assumptions were also tested by means of the model's independent variables. Furthermore, the model tests whether higher or lower productivity, average salary levels and profitability level affect the probability for a selected enterprise to become grant beneficiary. Business conditions are often driven by social and economic conditions in the enterprise's immediate surroundings, which makes regional affiliation another control variable in the model.

The majority of professional literature on the topic of the effect of grants from EU funds uses most of the variables described above in probit models. However, having in mind specific circumstances of Croatian non-financial corporations, this research introduced additional independent variables in the probit model, which have, for one reason or another, been estimated to affect the probability of obtaining a grant. As highlighted in the competent ministries' programme documents related to the policies of using grants from EU funds, Croatia has virtually no risk capital market, while a relatively small number of SMEs are not in a position to obtain bank funding (OP Competitiveness and Cohesion 2014-2020, September 2017). In addition, high indebtedness levels are one of the most pressing structural problems of the non-financial enterprise sector (see Martinis and Ljubaj, 2017). We can therefore assume that, due to relatively high indebtedness levels, many enterprises are unable to obtain regular bank funding or obtain sufficient bank funding to finance their development projects in full. In such circumstances, EU funds are seen as an alternative source of funding, which is a hypothesis that was tested in the model. 
In July 2013, Croatia became a full EU member state, which opened up the common European market to many Croatian exporters and had a strong impact on the growth of the overall export of goods and services in years immediately following the accession. We can assume that exporters are in the greatest need for expanding their business and their production or other capacities, which raises the probability of obtaining EU funding. In addition, exposure to international competition that comes with taking part in international markets makes exporters the most competitive part of national economy, which makes them substantially different from non-exporters (see Valdec and Zrnc, 2014, 2019).

\section{ECONOMETRIC ANALYSIS RESULTS}

\subsection{RESULTS OF PROBIT MODEL AND PROPENSITY SCORE MATCHING}

Results of the probit model presented in table 1 are in line with the above hypotheses. Grant beneficiaries are more likely to be older enterprises with more employees and greater capital and export intensity of business. They are also enterprises with higher indebtedness levels but also with higher profitability. On the other hand, labour productivity and total factor productivity were not shown as statistically significant determinants of receiving a grant from EU funds, whereas in the case of average salary and import intensity, this depends on the sample used.

In line with the methodology described above, the obtained results of the probit model were used for matching the enterprises in the control group. As shown in the table in appendix 3, matching has been successful and differences in arithmetic means of selected indicators between the corporate beneficiaries and their control group counterparts are not statistically significant, which was not the case before matching. All cases recorded more or less identical results, even when a strict pre-defined caliper value is used, i.e., maximum tolerated difference in the estimated propensity score between the treated enterprises and the control group enterprises (table in appendix 3).

\section{Table 1}

Results of probit model

\begin{tabular}{|c|c|c|c|c|}
\hline \multirow[b]{2}{*}{ Indicator } & \multicolumn{2}{|c|}{ Basic pattern } & \multicolumn{2}{|c|}{ Extended pattern } \\
\hline & $\begin{array}{c}\text { Marginal } \\
\text { effects }\end{array}$ & $\begin{array}{l}\text { Standard } \\
\text { error }\end{array}$ & $\begin{array}{l}\text { Marginal } \\
\text { effects }\end{array}$ & $\begin{array}{l}\text { Standard } \\
\text { error }\end{array}$ \\
\hline Labour productivity & 0.076 & $(0.074)$ & 0.044 & $(0.032)$ \\
\hline TFP & 0.009 & $(0.065)$ & 0.017 & $(0.030)$ \\
\hline Enterprise age & $0.013 * * *$ & $(0.003)$ & $0.004 * * *$ & $(0.001)$ \\
\hline Employment rate & $0.221 * * *$ & $(0.028)$ & $0.186^{* * *}$ & $(0.014)$ \\
\hline Capital intensity & $0.024 * *$ & $(0.011)$ & $0.022 * *$ & $(0.003)$ \\
\hline Indebtedness rate & $0.046^{* * *}$ & $(0.016)$ & $0.045^{* * *}$ & $(0.007)$ \\
\hline Average salary & $0.093 *$ & $(0.057)$ & 0.011 & $(0.016)$ \\
\hline Profitability & $0.078^{* * *}$ & $(0.022)$ & $0.052 * * *$ & $(0.009)$ \\
\hline Export intensity & $0.047 * * *$ & $(0.016)$ & $0.023 * * *$ & $(0.007)$ \\
\hline
\end{tabular}




\begin{tabular}{|c|c|c|c|c|}
\hline \multirow[b]{2}{*}{ Indicator } & \multicolumn{2}{|c|}{ Basic pattern } & \multicolumn{2}{|c|}{ Extended pattern } \\
\hline & $\begin{array}{c}\text { Marginal } \\
\text { effects }\end{array}$ & $\begin{array}{l}\text { Standard } \\
\text { error }\end{array}$ & $\begin{array}{c}\text { Marginal } \\
\text { effects }\end{array}$ & $\begin{array}{c}\text { Standard } \\
\text { error }\end{array}$ \\
\hline Import intensity & -0.002 & $(0.019)$ & $0.033 * * *$ & $(0.008)$ \\
\hline $\begin{array}{l}\text { Control variables } \\
\text { year }\end{array}$ & \multicolumn{2}{|c|}{ Yes } & \multicolumn{2}{|c|}{ Yes } \\
\hline NACE sector & \multicolumn{2}{|c|}{ Yes } & \multicolumn{2}{|c|}{ Yes } \\
\hline region & \multicolumn{2}{|c|}{ Yes } & \multicolumn{2}{|c|}{ Yes } \\
\hline Number of corporate beneficiaries & \multicolumn{2}{|c|}{227} & \multicolumn{2}{|c|}{1,643} \\
\hline Number of observations & \multicolumn{2}{|c|}{476,682} & \multicolumn{2}{|c|}{482,503} \\
\hline McFadden Pseudo $\mathrm{R}^{2}$ & \multicolumn{2}{|c|}{0.3251} & \multicolumn{2}{|c|}{0.2665} \\
\hline
\end{tabular}

Note: *,** and *** mark statistical significance levels of $10 \%, 5 \%$ and $1 \%$ respectively. The basic pattern pertains to 227 corporate beneficiaries that received their first EU grant no later than 2016. These enterprises were used throughout the analysis. On the other hand, the extended pattern pertains to all corporate beneficiaries after sample adjustments, including those that received their first grant after 2016.

Source: Authors' own calculation based on data by the Ministry of Finance, Financial Agency and Court Registry.

\subsection{RESULTS OF THE DIFFERENCE IN DIFFERENCES METHOD}

As visible in tables 2 and 3, the quantifications of the effects of receiving grants from EU funds show that EU grants had a strong positive effect on the majority of the twelve observable indicators of business performance and features for corporate beneficiaries. However, the effect of the grant was not equally apparent throughout the observed period; rather, for the majority of indicators it gradually increased as more time passed from the initial allocation. For some variables, the effect in the first two years ( $t$ and $t+1)$ was non-existent or not statistically significant and only became evident in the last year under observation $(t+2)$.

For measuring the effect of EU grants on the trends in the corporate beneficiaries' outputs, we selected two indicators - change in operating income and change in total added value. As visible from table 2, obtaining an EU grant had a strong positive effect on the growth dynamics of operating income and total added value, both in the year the support was received and in the two years that followed. The results show statistical significance in all calculations conducted with more enterprises in the control sample as well as when caliper is used (for additional calculations see appendix 4 below). Depending on the number of enterprises in the control sample, an enterprise's operating income rises up to $20 \%$ quicker in the year the grant was allocated $(t)$ than is the case with enterprises in the control sample, between $20 \%$ to $30 \%$ quicker in the year following the year of allocation $(t+1)$, while two years after the allocation $(t+2)$ this difference grows above $30 \%$. The results for the total added value indicator are very similar to operating income quantifications and their effect also rises as more time passes from the initial allocation of the support. 
TABLE 2

Results of the analysis of selected indicators by applying the difference in differences method

\begin{tabular}{|c|c|c|c|c|c|}
\hline \multirow[t]{2}{*}{ Indicator } & \multirow[t]{2}{*}{ Period } & \multicolumn{2}{|c|}{ No caliper } & \multicolumn{2}{|c|}{ Caliper (0.05) } \\
\hline & & 1 & 5 & 1 & 5 \\
\hline \multirow{3}{*}{ Operating income } & $\mathrm{t}$ & $0.213 * * *$ & $0.163 * *$ & $0.319 * *$ & $0.138 * * *$ \\
\hline & $t+1$ & $0.173 *$ & $0.257^{* *}$ & $0.290 * * *$ & $0.270 * * *$ \\
\hline & $t+2$ & $0.286^{* * *}$ & $0.295 * * *$ & $0.236^{*}$ & $0.317 * * *$ \\
\hline \multirow{3}{*}{ Added value } & $\mathrm{t}$ & $0.167 * * *$ & $0.126^{* * *}$ & $0.141^{* *}$ & $0.102 * * *$ \\
\hline & $t+1$ & $0.213 * * *$ & $0.240 * * *$ & $0.311 * * *$ & $0.244 * * *$ \\
\hline & $t+2$ & $0.332 * * *$ & $0.353 * * *$ & $0.388 * * *$ & $0.321 * * *$ \\
\hline \multirow{3}{*}{ Fixed assets } & $\mathrm{t}$ & $0.513 * * *$ & $0.502 * * *$ & $0.488 * * *$ & $0.516^{* * *}$ \\
\hline & $t+1$ & $0.610 * * *$ & $0.659 * * *$ & $0.721 * * *$ & $0.679 * * *$ \\
\hline & $t+2$ & $0.580 * * *$ & $0.658 * * *$ & $0.868 * * *$ & $0.636 * * *$ \\
\hline \multirow{3}{*}{ Employment rate } & $\mathrm{t}$ & $0.076^{* * *}$ & $0.069 * * *$ & $0.103 * * *$ & $0.080 * * *$ \\
\hline & $t+1$ & $0.106^{* * *}$ & $0.129 * * *$ & $0.235^{* * *}$ & $0.167 * * *$ \\
\hline & $\mathrm{t}+2$ & $0.141 * * *$ & $0.180 * * *$ & $0.270 * * *$ & $0.201 * * *$ \\
\hline \multirow{3}{*}{ Labour productivity } & $\mathrm{t}$ & $0.080 *$ & 0.050 & 0.031 & 0.014 \\
\hline & $\mathrm{t}+1$ & $0.094 *$ & $0.100 * *$ & 0.054 & 0.061 \\
\hline & $t+2$ & $0.175^{* * *}$ & $0.158 * * *$ & 0.098 & $0.103 * *$ \\
\hline \multirow{3}{*}{ TFP } & $\mathrm{t}$ & 0.062 & 0.033 & 0.018 & -0.002 \\
\hline & $\mathrm{t}+1$ & 0.059 & 0.084 & 0.092 & 0.072 \\
\hline & $\mathrm{t}+2$ & $0.160 * *$ & $0.171 * * *$ & $0.161 * *$ & $0.139 * * *$ \\
\hline \multicolumn{2}{|c|}{ Number of treated observations } & 226 & 226 & 219 & 215 \\
\hline \multicolumn{2}{|c|}{ Number of control observations } & 218 & 985 & 212 & 933 \\
\hline
\end{tabular}

Note: *, ** and *** mark statistical significance levels of $10 \%, 5 \%$ and $1 \%$ respectively. Statistical significance was determined by means of a bootstrapping procedure with 500 repetitions.

Source: Authors' own calculation based on data by the Ministry of Finance, Financial Agency and Court Registry.

We might wonder what aspect of the corporate beneficiary changed in the observation period after receiving support that caused the quicker output growth. This can be caused, on the one hand, by a stronger growth of business capacities or, on the other hand, by quicker growth of labour productivity and total factor productivity. The obtained calculations can lead to the conclusion that the notably quicker growth of outputs with corporate beneficiaries is a combination of both options referred to above, i.e., both more intense growth of labour productivity and stronger increase of total factor productivity.

Corporate beneficiaries throughout the observation period recorded up to $70 \%$ more dynamic growth of the value of fixed assets relative to enterprises in the control group. Even though this is quite a substantial difference, it is also not unexpected considering the purpose of the grants from EU funds referred to above, where one of the priorities is stimulating capital investment in production capacities. Despite being notably weaker than in the case of fixed assets, the effect on 
employment growth dynamics was also quite significant, but in the case of employment indicators the effect growth becomes apparent as more time passes from the initial allocation. In line with this, corporate beneficiaries recorded $7 \%$ to $8 \%$ more intense growth of total employee numbers in the year the grant was allocated $(t)$ compared to enterprises in the control group, while in the following year $(t+1)$ this effect grew to the $10 \%-16 \%$ range, depending on the calculation used, while in the last year under observation $(t+2)$, the total employee numbers increased by as much as $22 \%$.

Considering the above, we should ask the question about the trends in labour productivity and total factor productivity. The results suggest that the year the support was obtained $(t)$ as well as the following year $(t+1)$ recorded more intense growth of labour productivity and total factor productivity compared to enterprises in the control group, but the obtained results were not statistically significant in all calculation combinations with more enterprises in the control sample, so these results should be taken with a degree of caution. However, the last year under observation $(t+2)$ recorded a notably more intense growth of both productivity indicators with high statistical significance for both quantifications, most notably with total factor productivity. The growth in labour productivity recorded by corporate beneficiaries two years after obtaining support was up to $17 \%$ higher, while the growth of total labour productivity was up to $18 \%$ higher than was the case with enterprises in the control group.

These results related to productivity indicators can partially be explained through the assumption that enterprises need longer time to train new employees or perhaps use new machinery and equipment in its full capacity, which is why the effect on productivity becomes apparent only near the end of the observation period. However, the results related to the productivity trends are highly significant, since they show that the grants from EU funds not only facilitate more intense enterprise growth but also affect productivity growth rates, which makes the corporate beneficiary more competitive both on the domestic and international market.

In addition, it is a well-known fact that grants from EU funds may only be used to co-finance projects, while the remaining funds need to be collected from other sources. For this reason, this research also monitors indebtedness level trends of corporate beneficiaries and enterprises in the control group. As visible in table 3, the obtained results verify the assumption regarding the quicker growth of indebtedness, i.e., corporate beneficiaries' indebtedness levels throughout the three-year observation period have grown notably quicker than was the case with enterprises in the control group, while the effect enhances as more time passes after obtaining support. Apart from indebtedness levels, an additional issue is whether enterprises undergo other structural changes in business performance. For instance, does the grant obtained from EU funds enable corporate beneficiaries to pay higher salaries than enterprises from the control group? Quantifications obtained in this regard are extremely low and are not statistically significant. On the other hand, the 
results show that, despite employee numbers growing, corporate beneficiaries' capital intensity is even higher, i.e., the effect of the grant is stronger on the capital factor than on the labour factor.

\section{TABle 3}

Results of the analysis of selected indicators by applying the difference in differences method

Number of nearest neighbours

\begin{tabular}{|c|c|c|c|c|c|}
\hline \multirow[t]{2}{*}{ Indicator } & \multirow[t]{2}{*}{ Period } & \multicolumn{2}{|c|}{ No caliper } & \multicolumn{2}{|c|}{ Caliper (0.05) } \\
\hline & & 1 & 5 & 1 & 5 \\
\hline \multirow{3}{*}{ Indebtedness rate } & $\mathrm{t}$ & $0.156^{*}$ & $0.176^{* * *}$ & $0.179 *$ & $0.171 * *$ \\
\hline & $\mathrm{t}+1$ & $0.267 * *$ & $0.274 * * *$ & $0.324 * * *$ & $0.264 * * *$ \\
\hline & $t+2$ & $0.334 * *$ & $0.294 * * *$ & $0.300 * *$ & $0.296 * * *$ \\
\hline \multirow{3}{*}{ Average salary } & $\mathrm{t}$ & 0.005 & -0.008 & 0.008 & -0.006 \\
\hline & $t+1$ & -0.026 & -0.007 & -0.022 & -0.003 \\
\hline & $t+2$ & 0.035 & 0.021 & $0.044 *$ & 0.029 \\
\hline \multirow{3}{*}{ Capital intensity } & $\mathrm{t}$ & $0.539 * * *$ & $0.503 * * *$ & $0.444 * *$ & $0.510 * * *$ \\
\hline & $t+1$ & $0.567 * * *$ & $0.577 * * *$ & $0.547 * *$ & $0.551 * * *$ \\
\hline & $t+2$ & $0.476^{* *}$ & $0.507 * * *$ & $0.657 * * *$ & $0.453 * *$ \\
\hline \multirow{3}{*}{ Profitability } & $\mathrm{t}$ & -0.034 & -0.057 & -0.081 & -0.098 \\
\hline & $\mathrm{t}+1$ & -0.143 & -0.115 & $-0.197 * *$ & $-0.214 * * *$ \\
\hline & $t+2$ & -0.136 & $-0.169^{*}$ & $-0.320 * * *$ & $-0.255^{* * *}$ \\
\hline \multirow{3}{*}{ Export intensity } & $\mathrm{t}$ & -0.084 & -0.011 & 0.015 & -0.004 \\
\hline & $\mathrm{t}+1$ & $-0.166^{*}$ & -0.083 & -0.037 & -0.045 \\
\hline & $t+2$ & -0.161 & -0.058 & 0.027 & -0.007 \\
\hline \multirow{3}{*}{ Import intensity } & $\mathrm{t}$ & 0.021 & 0.005 & 0.113 & 0.066 \\
\hline & $\mathrm{t}+1$ & 0.005 & -0.003 & 0.168 & 0.074 \\
\hline & $\mathrm{t}+2$ & 0.094 & 0.131 & 0.191 & $0.159 *$ \\
\hline \multicolumn{2}{|c|}{ Number of treated observations } & 226 & 226 & 219 & 215 \\
\hline \multicolumn{2}{|c|}{ Number of control observations } & 218 & 985 & 212 & 933 \\
\hline
\end{tabular}

Note: *,** and *** mark statistical significance levels of 10\%, 5\% and 1\% respectively. Statistical significance was determined by means of a bootstrapping procedure with 500 repetitions. Additional calculations with control samples comprising 2 and 10 nearest neighbours are provided in appendix 4 below.

Source: Authors' own calculation based on data by the Ministry of Finance, Financial Agency and Court Registry.

However, with regard to corporate beneficiaries' profitability, no unambiguous reply can be provided. The obtained results show that profitability growth recorded by corporate beneficiaries in the years after receiving the support is notably slower than the growth recorded by enterprises in the control group, which may, at first sight, seem contrary to the previous results for other performance indicators, which showed a highly positive effect. Several explanations can be provided. In this research, we used the relative indicator of profitability - return on assets (ROA), which means that relative profitability, i.e., the total utilization rate of an asset unit, recorded slower growth or drop, but the enterprise's profitability in absolute terms grew. 
Namely, the projects under consideration may be of questionable profitability if they were financed by the enterprise's own funds or debt capital because the rise in operating income due to expansion of business would not cover the costs of depreciation and servicing of new debt. In addition, every project assumes a certain return rate for the investor; if the European projects under observation were funded only by the enterprise's own and/or debt capital instead of EU grants, they would be unable to meet the required return-on-investment rate and would be seen as less profitable. On the other hand, another explanation is possible, one that is closely connected to the capital budgeting theory, which assumes that in limited financing situations an enterprise would pursue the most profitable projects at the expense of less profitable ones. EU support provides an enterprise with an additional source of capital which can be used to materialise even less profitable projects. This would make relative profitability decrease or grow at a slower pace relative to enterprises in the control sample, whereas absolute profitability would grow. However, this does not mean that in more developed financial market conditions, where small and medium enterprises have more access to financing, such projects would not be materialised.

Finally, positive economic effects of support from EU funds are often disputed through assumed strong import growth. Since the results show that EU grants genuinely facilitate an increase in enterprises' business capacities and sales rates, it would be reasonable to expect import rates to record intense growth considering the Croatian economy being import-dependent. However, it is still unknown whether import growth is disproportionate to enterprise growth, i.e., whether import rates grow at a quicker pace than sales revenue, which would represent a growth in import intensity or import dependence of the enterprise under observation. The obtained results show that corporate beneficiaries did not record growth neither in their export nor import intensity in the years after receiving support.

\subsection{ESTIMATE OF THE RELATIONSHIP BETWEEN SIZE OF SUPPORT AND LEVEL OF IMPACT (DOSE-RESPONSE)}

An additional question to be answered is whether there is a difference in the level of the impact depending on the size of the received support, i.e., what is the lowest amount of grant that gives rise to positive effects on corporate beneficiaries' business performance. Findings related to the ratio between relative size of the received grant and level of impact can have notable policy implications, in this case competent bodies that, together with EU institutions, create policies for allocating grants from EU funds. Public grants always run into the risk of becoming inefficient or unattractive for the target group when the programme attempts to enhance its outreach at the expense of relative size of the support. 
Estimate of the relationship between grant size and impact level on trends in operating income (left) and total employment rate (right)
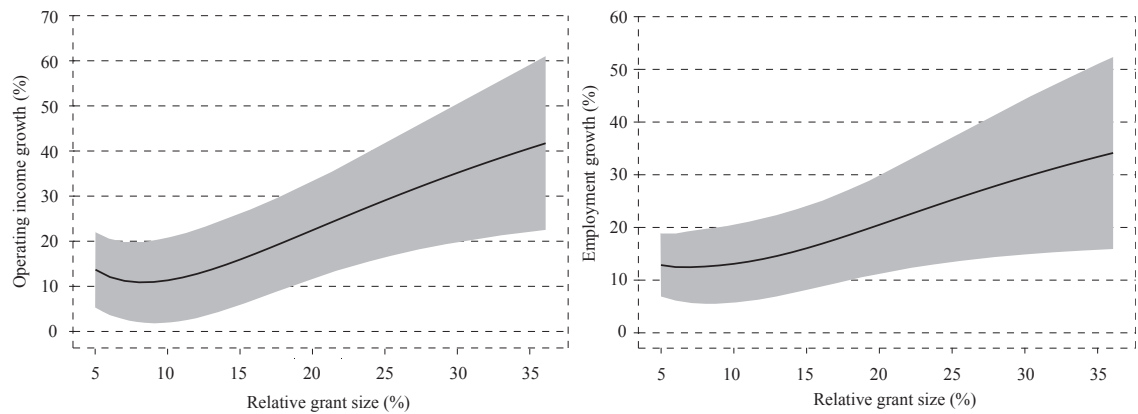

Note: The solid black curve depicts the conditional expectation of growth rates of the indicator under observation with the provided relative intensity of treatment and estimated generalised propensity score. The shadowed sections represent the ceiling and floor values of the $95 \%$ confidence interval calculated through the bootstrapping method with 500 repetitions.

Source: Authors' own calculation based on data by the Ministry of Finance, Financial Agency and Court Registry.

Figure 1 shows the results of the estimate regarding the effects of EU grants on trends in employment numbers and operating income for enterprises under observation in relation to the relative size of the received grant. As visible in the figures above, the curve starts out flat for both indicators, which leads to the conclusion that grants whose relative size is below $10 \%$ of a corporate beneficiary's operating income have a roughly equal and relatively weak effect on trends in employment numbers and operating income of enterprises under observation in the period after receiving the grant. However, above this threshold the effect of the grant is more prominent and grows more extensively as the relative size of the received grant increases. For instance, enterprises that received a grant in the amount of $35 \%$ of their operating income can expect their operating income to grow four times quicker while their employment numbers on the basis of hours of labour could grow three times quicker. However, growth of the grant size is accompanied by an increase in confidence intervals. For this reason, all conclusions should be taken with a degree of caution.

These results can partially be explained by the fact that enterprises apply to public tenders for a variety of business reasons. Low-impact grants are mostly used by enterprises whose objective is to enhance their current performance, e.g., by procuring new machinery or equipment to replace old or less efficient machinery, but not necessarily for expanding their business. Such enterprises are not in dire need for new recruits, which is part of the reason why the employment rate curve starts out flat. Conversely, beneficiaries of relatively large grants are those enterprises that use EU funds to co-finance the expansion of their business or boost their production and sales numbers, which is why they need a substantially larger grant to finance a capital intense investment and recruit additional employees. 


\section{Figure 2}

Estimate of the relationship between grant size and impact level on trends in corporate beneficiaries' capital intensity (left) and indebtedness levels (right)
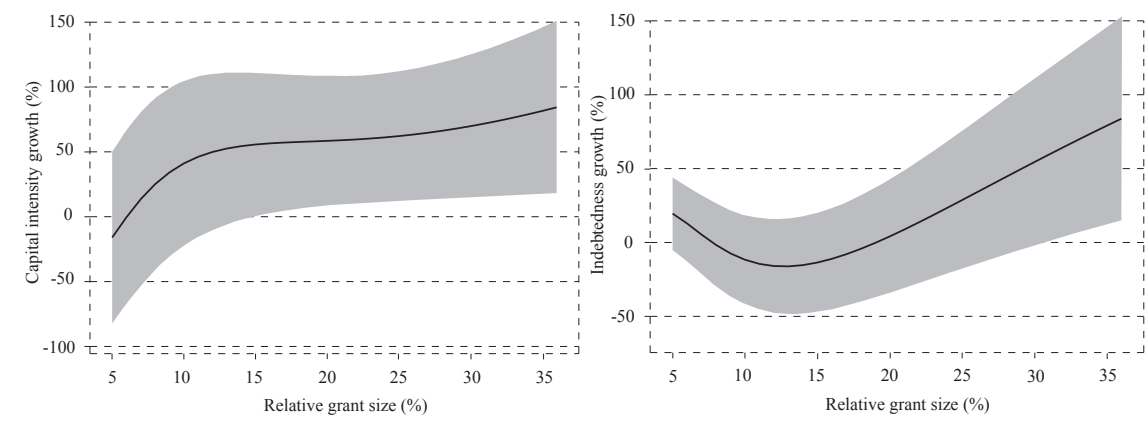

Note: The solid black curve depicts the conditional expectation of growth rates of the indicator under observation with the provided relative intensity of treatment and estimated generalised propensity score. The shadowed sections represent the ceiling and floor values of the $95 \%$ confidence interval calculated through the bootstrapping method with 500 repetitions.

Source: Authors' own calculation based on data by the Ministry of Finance, Financial Agency and Court Registry.

Such an explanation is supported by the obtained results regarding the trends in corporate beneficiaries' capital intensity and indebtedness levels. As visible in figure 2 (left), the effect on the growing trend of capital intensity is the strongest up to grant size of $10 \%$, as seen by the steep incline of the curve, while the effect above this threshold is still quite strong but with the curve much flatter. Taking into account the method for calculating capital intensity of business as the ratio between the value of fixed assets and employment rates expressed in hours of labour, the previous hypothesis can be corroborated. The commercial reason behind taking a relatively smaller grant is the enhancement of current business, for instance by procuring new machinery, which increases the value of the enterprise's fixed assets (because existing equipment has already been depreciated), while there is no need for new employees. For this reason, the capital intensity of business, expressed through the ratio above, grows. However, in cases where an enterprise uses EU support to finance the expansion of its business activities, for instance, by procuring new equipment and recruiting new employees, the business capital intensity grows more steadily and the curve is flatter.

The estimate of the relationship between the relative size of the grant and effect on the trends in enterprises' indebtedness levels leads to more-or-less the same conclusions (figure 2 right). Enterprises that implement financially less substantial projects (projects worth up to $10 \%$ of operating income), apart from co-financing provided by the EU, usually cover the rest of the required amount from their own revenues. In such cases, the received grant increases the value of the enterprise's property on the asset side and capital on the liability side, while the level of debt financing remains the same, which ultimately leads to a drop in indebtedness levels expressed as the share of commitments in sources of financing. On the other hand, projects that 
are used for substantially expanding enterprises' business activities carry a greater financial burden notwithstanding EU support. The remaining amount of co-financing cannot be covered from the enterprise's own resources and enterprises resort to debt financing of the remaining amount, which increases their indebtedness indicator and the curve of the estimated effect changes direction after crossing the $10 \%$ relative grant size benchmark. Despite being merely indicative, these conclusions should be taken with a degree of caution due to relatively wide confidence intervals caused by a relatively small number of observations.

\section{Figure 3}

Estimate of the relationship between grant size and impact level on trends in total factor productivity (left) and labour productivity (right)
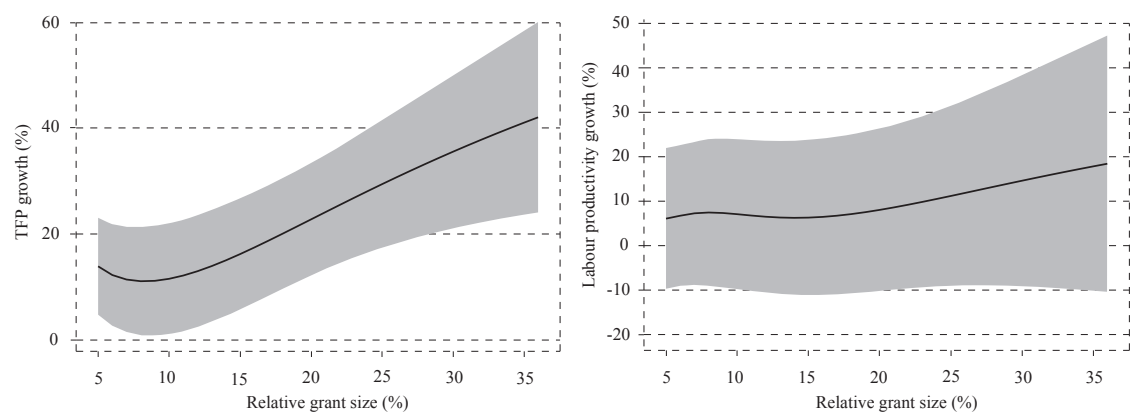

Note: The solid black curve depicts the conditional expectation of growth rates of the indicator under observation with the provided relative intensity of treatment and estimated generalised propensity score. The shadowed sections represent the ceiling and floor values of the $95 \%$ confidence interval calculated through the bootstrapping method with 500 repetitions.

Source: Authors' own calculation based on data by the Ministry of Finance, Financial Agency and Court Registry.

Finally, productivity indicators provide no unambiguous conclusions (figure 3). Namely, as was the case with all indicators described above, the effect on total factor productivity trends grows notably after the relative size of the grant grows above the $10 \%$ threshold of the enterprise's operating income. However, in the case of labour productivity, the curve is almost completely flat all the way up to relative grant size of $20 \%$ of operating income, with extremely wide confidence intervals. Despite limitations of the conducted analysis, the majority of the indicators considered demonstrate a positive relationship between relative size of the grant and level of impact, especially when relative grant size is higher than $10 \%$ of the enterprise's operating income.

This is an important conclusion in the context of overall efficiency and cost-effectiveness of the public policy under observation, more specifically the allocation of public grants from EU funds to the non-financial corporation sector. Since these grants are often very substantial in financial terms and cover up to $85 \%$ of the applied project value, there is a certain moral hazard risk - a situation in which an enterprise uses the grant to increase its production capacities for virtually no cost, 
despite there being no commercial reason for such a decision had the project been financed through the enterprise's own resources. We already discussed the issue of cost-effectiveness of European projects considering the obtained results regarding the effect of the grant on relative profitability trends. However, the results we obtained with regard to the causal relationship between grant size and impact level, especially when it comes to stronger growth of operating income in parallel to the growth of relative grant size, support the hypothesis that the grant allocation programme is, in fact, efficient.

In conclusion, the obtained results can be compared to similar research conducted for other countries. In general, one can say that the results are very similar and that other pieces of research also reveal several positive effects of receiving grants from EU funds on a variety of enterprises' performance indicators. If we compare our results to those in Benkovskis et al. (2018) or Bachtrogler and Hammer (2018), we can see that the findings are quite similar, in that the effect on employment numbers, revenue and capital intensity becomes visible soon after obtaining the grant. On the other hand, none of these papers was able to find an unambiguous effect on productivity. Bachtrogler and Hammer (2018) discover a short-term rise in enterprises' productivity levels only for a few countries and only depending on the variable definition. Similar to the present research, Benkovskis et al. (2018) find positive effects on productivity trends only after a few years have passed from receiving the grant.

\section{CONCLUSION}

This paper tried to answer several research questions, primarily the question regarding the effects of receiving grants from EU funds on business performance of non-financial corporations. The results show that the support obtained from EU funds had a strong positive effect on the majority of the twelve selected performance indicators and business features of corporate beneficiaries. If we look at the individual indicators, the obtained results show that corporate beneficiaries, when compared to enterprises in the control group, recorded a notable growth in outputs in the period after receiving the grant, expressed as either trends in operating income or total added value generated. The intensification of the enterprises' output growth dynamics arises due to quicker growth of production factors, i.e., labour and capital. In addition, the analysis also determined significant and positive effects of the obtained EU grant on the enterprises' productivity, expressed as either labour productivity or total factor productivity, especially two years after receiving the grant $(t+2)$.

The research has also shown that the grants resulted in structural changes, which led to the corporate beneficiaries' performance becoming more capital intense. At the same time, we recorded quicker growth of indebtedness levels since EU grants are used only for co-financing projects while the remaining amounts must be covered from other sources. In addition, the results show that profitability growth recorded by corporate beneficiaries in the years after receiving the grant is notably 
slower, which may, at first sight, seem contrary to the previous results for other performance indicators, which showed an extremely positive effect.

Apart from demonstrating the effect of grants received from EU funds, the paper also determined which business features of enterprises affect the probability of obtaining EU support. Results of the probit model showed that grant beneficiaries are more likely to be older enterprises with more employees and greater capital and export intensity of business. They are also enterprises with higher indebtedness levels but also with higher profitability. Average salary, labour productivity and total factor productivity as well as import intensity of business all failed to reach statistical significance for the probability of receiving the grant.

Finally, the paper estimated the relationship between the relative size of the grant and its level of impact. These results demonstrated the existence of a causal relationship and that the impact grows as the relative grant size grows, but only in cases when the grant exceeds $10 \%$ of operating income the enterprise collected in the year before receiving the grant. To the authors' best knowledge, this is the first professional paper to use the method above on the case of grants from EU funds.

As a conclusion, we should highlight that the slower utilization rate of grants from EU funds kept the focus of the public and competent authorities on improving the results regarding total utilization, considering the opportunity cost that would be incurred if such large amounts would remain unallocated. However, the utilization dynamics was substantially improved in the past several years and reached the average utilization rate at EU level according to some measures. For this reason, the competent authorities' next objective should be increasing the utilization rate in such a manner that the funds are allocated to those areas where they were successfully utilised. Research and analyses dealing with the effect of the grants on end beneficiaries are extremely important in this context. However, the significance of EU funds for Croatia is not reflected in the number of such analyses. This research is an attempt to improve the quality of public debate that should ultimately aim to improve the existing policy of using grants from EU funds.

\section{Disclosure statement}

No potential conflict of interest was reported by the authors. 
1. Ackerberg, D., Caves, K. and Garth, F., 2006. Structural identification of production functions. MPRA Paper, 38349.

2. Bachtrogler, J. and Hammer, C., 2018. Who are the beneficiaries of the structural funds and the cohesion fund and how does the cohesion policy impact firm-level performance? OECD Economics Department Working Papers, No. 1499. https://doi.org/10.1787/67947b82-en

3. Bartoluci, M. [et al.], 2018. Sredstva EU fondova u funkciji razvoja ruralnog turizma u Hrvatskoj. Acta Economica Et Turistica, 4(1), pp. 63-78.

4. Becker, B., Vanino, E. and Roper, S., 2019. Knowledge to money: assessing the business performance effects of publicly-funded R\&D grants. Research policy, 48(7), pp. 1714-1737. https://doi.org/10.1016/j.respol.2019.04.001

5. Benkovskis, K., Tkacevs, O. and Yashiro, N., 2018. Importance of EU Regional Support Programmes for Firm Performance. Latvijas Banka Working Papers, No. 2018/01.

6. Bouayad-Agha, S., Turpinn, N. and Vedrine, L., 2011. Fostering the development of European regions: A spatial dynamic panel data analysis of the impact of cohesion policy. Regional Studies, 47(9), pp. 1573-1593. https://doi.org/10. 1080/00343404.2011.628930

7. Breidenbach, P., Mitze, T. and Schmidt, C. M., 2016. EU Structural Funds and Regional Income Convergence - A sobering experience. CEPR Discussion Paper, No. 11210. https://doi.org/10.2139/ssrn.2758674

8. Cappelen, A. [et al.], 2003. The impact of EU regional support on growth and convergence in the European Union. Journal of Common Market Studies, 41(4), pp. 621-644. https://doi.org/10.1111/1468-5965.00438

9. Cerulli, G. and Poti, B., 2014. Public support intensity and company $R \& D$ performance: Evidence from a dose-response model. $54^{\text {th }}$ Congress of the European Regional Science Association: "Regional development \& globalisation: Best practices", 26-29 August 2014.

10. Crescenzi, R. and Giua, M., 2017. Different approaches to the analysis of EU cohesion policy. In: J. Bachtler [et al.], eds. EU cohesion policy. Reassessing performance and direction. London: Routledge. https://doi.org/10.4324/ 9781315401867

11. Dai, M., Li, X. and Lu, Y., 2017. How Urbanization Economies Impact TPF of R\&D Performers: Evidence from China. Sustainability, 9(10), pp. 1-17. https://doi.org/10.3390/SU9101766

12. Dai, X. and Cheng, L., 2015. The effect of public subsidies on corporate R\&D investment: An application of the generalized propensity score. Technological Forecasting \& Social Change, 90(Part B), pp. 410-419. https://doi.org/10. 1016/j.techfore.2014.04.014

13. Dall'Erba, S. and Le Gallo, J., 2007. Cohesion policy, the convergence process and employment in the European Union. Czech Journal of Economics and Finance, 57, pp. 324-340. 
14. Dall'Erba, S. and Le Gallo, J., 2008. Regional convergence and the impact of European structural funds over 1989-1999: A spatial econometric analysis. Papers in Regional Science, 87(2), pp. 219-244. https://doi.org/10.1111/j.14355957.2008.00184.x

15. Darvas, Z., Mazza, J. and Midoes, C., 2019. How to improve European Union cohesion policy for the next decade. Bruegel Policy Contribution, (8).

16. De Zwaan, M. and Merlevede, B., 2013. Regional policy and firm productivity. European Trade Study Group (ETSG) Working Paper, No. 377.

17. ECB, 2014. Micro-based evidence of EU competitiveness: The Compnet database. ECB Working paper series, No. 1634.

18. Ederveen, S. [et al.], 2002. Funds and games: The economics of European cohesion policy. ENEPRI Occasional Paper, No. 3.

19. Ederveen, S., De Groot, H. L. F. and Nahuis, R., 2006. Fertile soil for structural funds? A panel data analysis of the conditional effectiveness of European cohesion policy. Kyklos, 59(1), pp. 17-42. https://doi.org/10.1111/j.1467-6435. 2006.00318.x

20. Esposti, R. and Bussoletti, S., 2008. Impact of Objective 1 funds on regional growth convergence in the European Union: A panel data approach. Regional Studies, 42(2), pp. 159-173. https://doi.org/10.1080/00343400601142753

21. Fagerberg, J. and Verspagen, B., 1996. Heading for divergence? Regional growth in Europe reconsidered. JCMS: Journal of Common Market Studies, 34(3), pp. 431-448. https://doi.org/10.1111/j.1468-5965.1996.tb00580.x

22. Fattorini, L., Ghodsi, M. and Rungi, A., 2018. Cohesion Policy Meets Heterogeneous Firms. WIIW Working Paper, No. 142. https://doi.org/10.2139/ssrn.3488374

23. Ferrara, A. R. [et al.], 2016. Assessing the impacts of cohesion policy on EU regions: A non-parametric analysis on interventions promoting research and innovation and transport accessibility. Papers in Regional Science, 96(4), pp. 817-841. https://doi.org/10.1111/pirs.12234

24. Fryges, H. and Wagner, J., 2008. Exports and Productivity Growth: First Evidence from a Continuous Treatment Approach. Review of World Economics, 144, pp. 695-722. https://doi.org/10.1007/s10290-008-0166-8

25. Galuscak, K. and Lizal, L., 2011. The Impact of Capital Measurement Error Correction on Firm-Level Production Function Estimation. Czech National Bank Working Papers, No. 2011/09.

26. Gelo, T. and Družić, M., 2015. Ukupna faktorska produktivnost sektora hrvatskoga gospodarstva. Ekonomska misao i praksa, 2(2015), pp. 327-344.

27. Hagen, T. and Mohl, P., 2009. Econometric evaluation of EU Cohesion policy - A survey. ZEW Discussion Paper, No. 09-052.

28. Hartsenko, J. and Sauga, A., 2013. The role of financial support in SME and economic development in Estonia. Business and Economic Horizons, 9(2), pp. 10-22. https://doi.org/10.15208/beh.2013.6 
29. Hirano, K. and Imbens, G. W., 2004. The propensity score with continuous treatments. Applied Bayesian modeling and causal inference from incompletedata perspectives, pp. 73-84. https://doi.org/10.1002/0470090456.ch7

30. Kersan Škabić, I. and Tijanić, L., 2017. Regional abrorption capacity of EU funds. Economic research - Ekonomska istraživanja, 30(1), pp. 1192-1208. https://doi.org/10.1080/1331677X.2017.1340174

31. Kotarski, V., 2016. European funding - Impact on Research Capacity in Croatia. Review of Innovation and Competitiveness: A Journal of Economic and Social Research, 2(3), pp. 47-64. https://doi.org/10.32728/ric.2016.23/3

32. Levinsohn, J. and Petrin, A., 2003. Estimating Production Functions Using Inputs to Control for Unobservables. Review of Economic Studies, 70(2), pp. 317-341. https://doi.org/10.1111/1467-937X.00246

33. Maleković, S., Puljiz, J. and Keser, I., 2017. The Impact of Cohesion Policy on Croatia 's Regional Policy and Development. Zagreb: Institute for Development and International Relations.

34. Martinis, A. and Ljubaj, I., 2017. Prekomjerni dug poduzeća u Hrvatskoj: mikroprocjena i makroimplikacije. HNB Istraživanja, I-52.

35. Marzinotto, B., 2012. The growth effects of EU Cohesion policy: A metaanalysis. Bruegel Working Paper, No. 2012/14.

36. Medić, M., Hadrović Zekić, B. and Sabljo, V., 2017. Impact of EU Funds on Regional Development. In: U. Bacher [et al.], eds. Interdisciplinary Management Research XIII, pp. 1060-1077.

37. MINGO, 2017. Operativni program Konkurentnost i kohezija 2014.-2020. - tehničke izmjene. Zagreb: MINGO.

38. Moral Arce, I. and Paniagua San Martin, M., 2016. An impact evaluation of the EU funds on research and development in Spanish companies in 20072011. Papeles de Trabajo del Instituto de Estudios Fiscales, No. 7.

39. Olley, G. S. and Pakes, A., 1996. The dynamics of productivity in the telecommunications equipment industry. Econometrica, 64(6), pp. 1263-1297. https:// doi.org/10.2307/2171831

40. Ott, K., Bronić, M. and Stanić, B., 2018. EU grants to Croatian counties, cities and municipalities 2015-2016. Newsletter: an occasional publication of the Institute of Public Finance, No. 114.

41. Pienkowski, J. and Berkowitz, P., 2015. Econometric assessments of Cohesion Policy growth effects: How to make them more relevant for policy makers? European Commission Working Paper, No. 02/2015.

42. Poljičak, A., 2017. The synergy of public procurement and management for projects financed from the European structural and investment funds. Journal of Accounting \& Management, 7(1), pp. 57-68.

43. Rodriguez-Pose, A. and Fratesi, U., 2004. Between development and social policies: The impact of European structural funds in Objective 1 regions. Regional Studies, 38(1), pp. 97-113. https://doi.org/10.1080/00343400310001632226 
44. Rosenbaum, P. R. and Rubin, D., 1983. The Central Role of the Propensity Score in Observational Studies for Causal Effects. Biometrika, 70(1), pp. 41-55. https://doi.org/10.1093/biomet/70.1.41

45. Sikirić, S., Sikirić, A. and Vašiček, D., 2015. Lokalni proračun i programsko planiranje u funkciji financiranja projekata iz EU fondova. Business Consultant / Poslovni Konsultant, 7(51), pp. 31-42.

46. Šostar, M. and Marukić, A., 2017. Challenges of public procurement in EU funded projects. Journal of Contemporary Management Issues, 22(2), pp. 99-113. https://doi.org/10.30924/mjcmi/2017.22.2.99

47. Srhoj, S., Škrinjarić, B. and Radas, S., 2018. Bidding against the odds? The impact evaluation of grants for young micro and small firms during the recession. Radni materijali EIZ-a, 2(2018), pp. 5-37.

48. Valdec, M. and Zrnc, J., 2015. The direction of causality between exports and firm performance: microeconomic evidence from Croatia using the matching approach. Financial Theory and Practice, 39(1), pp. 1-30. https://doi.org/ 10.3326/fintp.39.1.1

49. Valdec, M. and Zrnc, J., 2019. Karakteristike hrvatskih izvoznika iz prerađivačkog sektora i oporavak izvoza tijekom velike recesije - rezultati istraživanja modula za trgovinu Istraživačke mreže za konkurentnost (CompNet). HNB Pregledi P-42.

50. Viskovic, J. and Udovičić, M., 2017. Awareness of SMEs on the EU Funds Financing Possibilities: The Case of Split-Dalmatia County. KnE Social Sciences, 1(2), pp. 319-332.

51. Wooldridge, J. M., 2009. On estimating firm-level production functions using proxy variables to control for unobservables. Economics Letters, 104(3), pp. 112114. 
APPENDIX 1

LIST OF VARIABLES USED IN THE ANALYSIS

\begin{tabular}{|c|c|c|}
\hline Variable name & Description & Note \\
\hline Revenue & $\begin{array}{l}\text { Real value of operating } \\
\text { income }\end{array}$ & Deflated by GDP deflator \\
\hline Employment rate & $\begin{array}{l}\text { Total number of employees } \\
\text { based on hours of labour }\end{array}$ & - \\
\hline Fixed assets & Real value of fixed assets & Deflated by GDP deflator \\
\hline Age & $\begin{array}{l}\text { Number of years passed } \\
\text { since the establishment } \\
\text { of the enterprise }\end{array}$ & 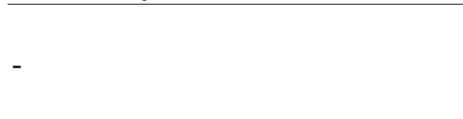 \\
\hline Added value & $\begin{array}{l}\text { Difference between } \\
\text { operating income and value } \\
\text { of intermediary inputs and } \\
\text { other costs of sold products }\end{array}$ & $\begin{array}{l}\text { Deflated by implicit added value } \\
\text { deflators to the second digit level } \\
\text { of the National Classification of } \\
\text { Activities (NACE). Energy costs } \\
\text { have been deflated by the implicit } \\
\text { added value deflator for the } \\
\text { electricity, gas, steam and air } \\
\text { conditioning supply sector }\end{array}$ \\
\hline $\begin{array}{l}\text { Labour } \\
\text { productivity }\end{array}$ & $\begin{array}{l}\text { Ratio between added value } \\
\text { and number of employees }\end{array}$ & 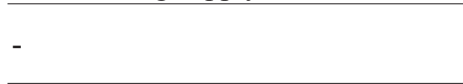 \\
\hline $\begin{array}{l}\text { Total factor } \\
\text { productivity }\end{array}$ & $\begin{array}{l}\text { Residual of the Cobb- } \\
\text { Douglas production function }\end{array}$ & $\begin{array}{l}\text { See appendix } 2 \text { for more details } \\
\text { on calculation methodology }\end{array}$ \\
\hline Capital intensity & $\begin{array}{l}\text { Ratio between fixed assets } \\
\text { and number of employees }\end{array}$ & ( \\
\hline Profitability & $\begin{array}{l}\text { Ratio between period profit } \\
\text { and total assets }\end{array}$ & - \\
\hline Indebtedness rate & $\begin{array}{l}\text { Ratio between non-current } \\
\text { liabilities and total } \\
\text { commitments }\end{array}$ & - \\
\hline Average salary & $\begin{array}{l}\text { Ratio between total gross } \\
\text { employee costs and number } \\
\text { of employees }\end{array}$ & $\begin{array}{l}\text { Deflated by implicit added value } \\
\text { deflators to the second digit level } \\
\text { of the National Classification } \\
\text { of Activities (NACE) }\end{array}$ \\
\hline Export intensity & $\begin{array}{l}\text { Ratio between revenue from } \\
\text { sales abroad and operating } \\
\text { income }\end{array}$ & ( \\
\hline Import intensity & $\begin{array}{l}\text { Ratio between import value } \\
\text { and operating income }\end{array}$ & - \\
\hline $\begin{array}{l}\text { Regional } \\
\text { affiliation }\end{array}$ & $\begin{array}{l}\text { Divided into five regions: } \\
\text { Eastern Croatia, Central } \\
\text { Croatia, Northern Croatia, } \\
\text { Adriatic Croatia and the } \\
\text { City of Zagreb }\end{array}$ & $\begin{array}{l}\text { An enterprise's geographic } \\
\text { affiliation is classified into regions, } \\
\text { which have been defined on the } \\
\text { basis of the first version of the new } \\
\text { NUTS-2 classification in Croatia } \\
\text { (Institute for Development and } \\
\text { International Relations, 2018). This } \\
\text { classification is used here solely for } \\
\text { analytical purposes }\end{array}$ \\
\hline
\end{tabular}


The starting point for calculating total factor productivity is the standard CobbDouglas production function, which can be expressed based on added value in logarithmic form as:

$$
r v a_{i t}=a_{i t}+\beta_{K} k_{i t}+\beta_{L} l_{i t}+\beta_{M} m_{i t}+\varepsilon_{i t}
$$

where $r v a_{i t}$ represents each enterprise's real added value, $a_{i t}$ denotes its efficacy level or residual, $k_{i t}$ represents fixed assets real value, $l_{i t}$ is total employment based on hours of labour, $m_{i t}$ denotes real value of material inputs used in the production process, while $\varepsilon_{i t}$ stands for estimate error. The methodology for calculating total factor productivity follows the approach developed by Olley and Pakes (1996) and its upgrade proposed by Levinsohn and Petrin (2003), Ackerberg et al. (2006), Wooldridge (2009) and Galuscak and Lizal (2011), i.e., the estimate is a thirdlevel polynomial model in the following form:

$$
\begin{aligned}
r v a_{i t}= & \beta_{0}+\beta_{1} k_{i t}+\beta_{2} k_{i(t-1)}+\beta_{3} m_{i(t-1)}+\beta_{4} k_{i(t-1)}^{2}+\beta_{5} m_{i(t-1)}^{2} \\
& +\beta_{6} k_{i(t-1)}^{3}+\beta_{7} m_{i(t-1)}^{3}+\beta_{8} k_{i(t-1)} m_{i(t-1)}+\beta_{9} k_{i(t-1)} m_{i(t-1)}^{2} \\
& +\beta_{10} k_{i(t-1)}^{2} m_{i(t-1)}+\gamma \text { Year }_{t}+\omega L_{i(t-1)}
\end{aligned}
$$

This approach is unique for using observable values of production inputs (after one year) as instruments for unobservable production shocks, which is important for controlling for simultaneity bias. The simultaneity bias arises due to the fact that, even though total factor productivity levels are not observable, they are known within an enterprise. In other words, any enterprise will, in any given period, select the optimal combination of production inputs in line with its production function after observing its own productivity levels. Ignoring the fact that labour, capital and material inputs are correlated to unobservable productivity at enterprise level can lead to inconsistent estimation of the production function (ECB, 2014). Since labour and total factor productivity are determined simultaneously, while material assets take time to develop, the instrumental variable used for measuring labour is its value one year after receiving the grant. The terms used in the estimated equation include material inputs and fixed assets up to third level and their interaction terms in order to account for their possible non-linear connection. The estimate also includes indicator control variables for the year, while standard errors have been grouped at enterprise level. For implementing the approach above, we use the generalized method of moments (GMM), similar to Wooldridge (2009).

After estimating the production function elasticity coefficients, the final step entails calculating total factor productivity, i.e., production function residual, of each enterprise through the following formula:

$$
T F P_{i t}=a_{i t}=r v a_{i t}-\left(\hat{\beta}_{0}+\hat{\beta}_{1} k_{i t}+\hat{\omega} L_{i(t-1)}+\hat{\gamma} \text { Year }_{t}\right)
$$



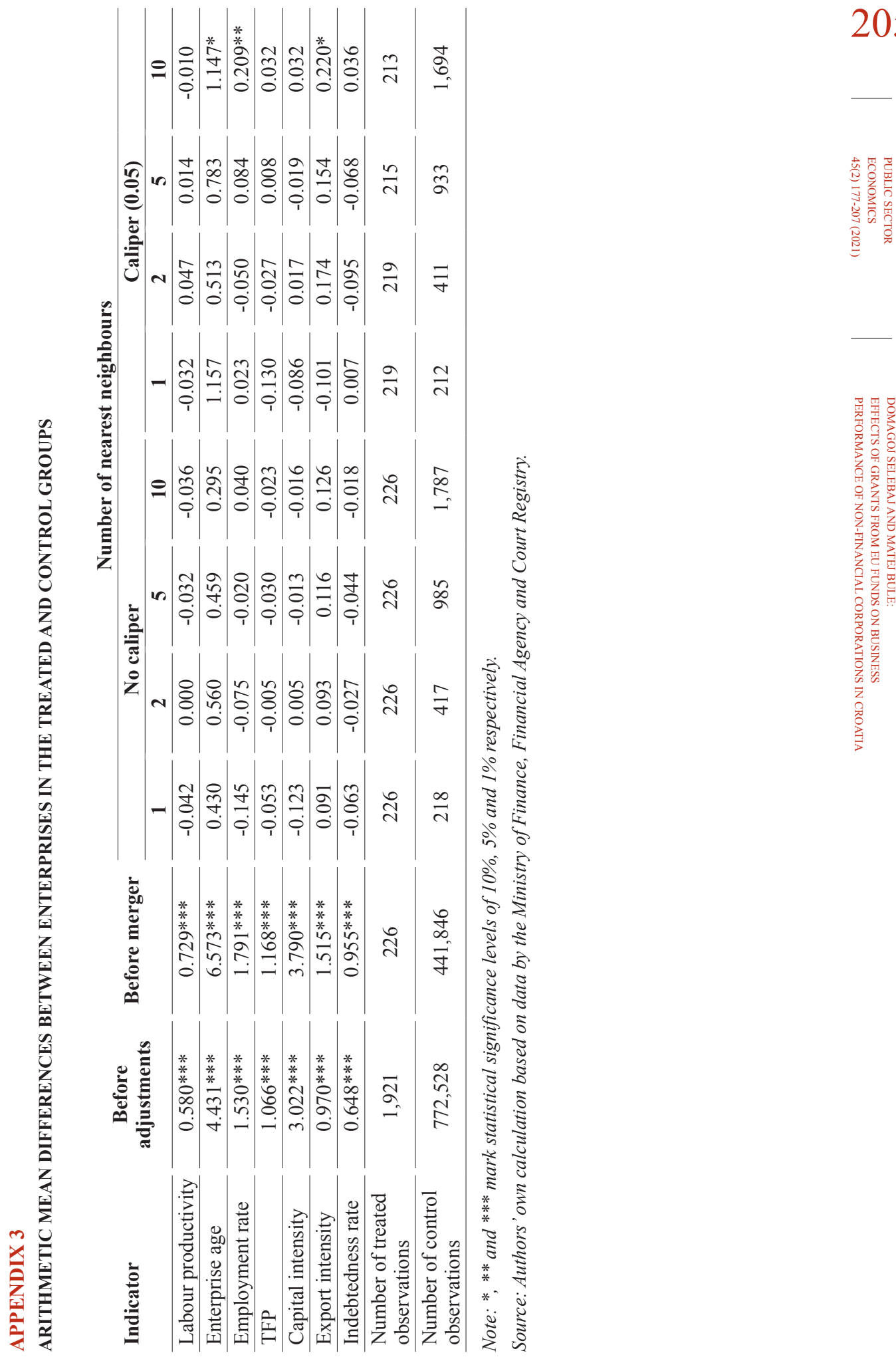
APPENDIX 4

ANALYSIS RESULTS FOR SELECTED BUSINESS PERFORMANCE INDICATORS THROUGH THE DIFFERENCE IN DIFFERENCES METHOD WITH CONTROL GROUP OF 2 AND 10 NEAREST NEIGHBOURS

\begin{tabular}{|c|c|c|c|c|c|}
\hline \multirow{3}{*}{ Indicator } & \multirow{3}{*}{ Period } & \multicolumn{4}{|c|}{ Number of nearest neighbours } \\
\hline & & \multicolumn{2}{|c|}{ No caliper } & \multicolumn{2}{|c|}{ Caliper (0.05) } \\
\hline & & 2 & 10 & 2 & 10 \\
\hline \multirow{3}{*}{ Operating income } & $\mathrm{t}$ & $0.200 * * *$ & $0.182 * * *$ & $0.219 * *$ & $0.210 * *$ \\
\hline & $t+1$ & $0.300^{* *}$ & $0.309 * * *$ & $0.288 * * *$ & $0.292 * * *$ \\
\hline & $t+2$ & $0.328 * * *$ & $0.324 * * *$ & $0.308 * * *$ & $0.346^{* * *}$ \\
\hline \multirow{3}{*}{ Added value } & $\mathrm{t}$ & $0.148^{* * *}$ & $0.134 * * *$ & $0.125 * *$ & $0.129 * * *$ \\
\hline & $\mathrm{t}+1$ & $0.248 * * *$ & $0.256^{* * *}$ & $0.227 * * *$ & $0.256^{* * *}$ \\
\hline & $t+2$ & $0.328 * * *$ & $0.375^{* * *}$ & $0.326 * * *$ & $0.364 * * *$ \\
\hline \multirow{3}{*}{ Fixed assets } & $\mathrm{t}$ & $0.506 * * *$ & $0.482 * * *$ & $0.470 * * *$ & $0.465 * * *$ \\
\hline & $t+1$ & $0.632 * * *$ & $0.695 * * *$ & $0.735^{* * *}$ & $0.748 * * *$ \\
\hline & $t+2$ & $0.582 * * *$ & $0.709 * * *$ & $0.709 * * *$ & $0.722 * * *$ \\
\hline \multirow{3}{*}{ Employment rate } & $\mathrm{t}$ & $0.073 * * *$ & $0.071 * * *$ & $0.080 * * *$ & $0.081 * * *$ \\
\hline & $t+1$ & $0.123 * * *$ & $0.142 * * *$ & $0.166^{* * *}$ & $0.160 * * *$ \\
\hline & $t+2$ & $0.187 * * *$ & $0.184 * * *$ & $0.220 * * *$ & $0.202 * * *$ \\
\hline \multirow{3}{*}{ Labour productivity } & $\mathrm{t}$ & 0.067 & 0.055 & 0.032 & 0.041 \\
\hline & $t+1$ & $0.113^{*}$ & $0.100 * *$ & 0.045 & $0.083^{*}$ \\
\hline & $t+2$ & $0.123 * *$ & $0.175 * * *$ & $0.087 *$ & $0.149 * * *$ \\
\hline \multirow{3}{*}{ TFP } & $\mathrm{t}$ & 0.057 & 0.039 & 0.026 & 0.024 \\
\hline & $t+1$ & $0.109 *$ & $0.089 *$ & 0.046 & $0.081 *$ \\
\hline & $t+2$ & $0.147 * * *$ & $0.189 * * *$ & $0.112 * *$ & $0.169 * * *$ \\
\hline \multirow{3}{*}{ Indebtedness rate } & $\mathrm{t}$ & $0.189 * *$ & $0.200 * * *$ & $0.165 * *$ & $0.200 * * *$ \\
\hline & $t+1$ & $0.348^{* * *}$ & $0.287 * * *$ & $0.317 * * *$ & $0.301 * * *$ \\
\hline & $t+2$ & $0.336^{* * *}$ & $0.289 * * *$ & $0.277 * *$ & $0.297 * * *$ \\
\hline \multirow{3}{*}{ Average salary } & $\mathrm{t}$ & -0.003 & 0.005 & -0.002 & 0.009 \\
\hline & $t+1$ & 0.016 & -0.003 & 0.019 & 0.001 \\
\hline & $\mathrm{t}+2$ & 0.014 & 0.029 & 0.023 & 0.042 \\
\hline \multirow{3}{*}{ Capital intensity } & $\mathrm{t}$ & $0.511^{* * *}$ & $0.474 * * *$ & $0.432 * * *$ & $0.457 * * *$ \\
\hline & $t+1$ & $0.557^{* * *}$ & $0.603 * * *$ & $0.620 * * *$ & $0.660 * * *$ \\
\hline & $t+2$ & $0.416^{* * *}$ & $0.571 * * *$ & $0.541 * * *$ & $0.585^{* * *}$ \\
\hline \multirow{3}{*}{ Profitability } & $\mathrm{t}$ & -0.028 & -0.052 & -0.083 & -0.105 \\
\hline & $t+1$ & -0.101 & $-0.130 *$ & $-0.145^{*}$ & $-0.183 * *$ \\
\hline & $t+2$ & $-0.178^{*}$ & $-0.192 * *$ & $-0.214 * *$ & $-0.259 * * *$ \\
\hline \multirow{3}{*}{ Export intensity } & $\mathrm{t}$ & -0.024 & -0.010 & -0.018 & 0.013 \\
\hline & $t+1$ & -0.079 & -0.079 & -0.096 & -0.055 \\
\hline & $t+2$ & -0.102 & -0.071 & -0.089 & -0.001 \\
\hline \multirow{3}{*}{ Import intensity } & $\mathrm{t}$ & 0.025 & 0.026 & 0.052 & 0.022 \\
\hline & $t+1$ & 0.021 & 0.052 & -0.001 & 0.034 \\
\hline & $\mathrm{t}+2$ & 0.163 & 0.121 & 0.075 & 0.128 \\
\hline \multicolumn{2}{|c|}{ Number of treated observations } & 226 & 226 & 219 & 213 \\
\hline \multicolumn{2}{|c|}{ Number of control observations } & 417 & 1,787 & 411 & 1,694 \\
\hline
\end{tabular}

Note: *,**and *** mark statistical significance levels of $10 \%, 5 \%$ and $1 \%$ respectively. Statistical significance was determined by means of a bootstrapping procedure with 500 repetitions.

Source: Authors' own calculation based on data by the Ministry of Finance, Financial Agency and Court Registry. 
APPENDIX 5

GENERALISED PROPENSITY SCORE (GPS) ESTIMATES

\begin{tabular}{|c|c|c|}
\hline Indicator & Coefficient & Standard error \\
\hline Employment rate & $-0.495^{* * *}$ & 0.085 \\
\hline Capital intensity & $-0.074 * *$ & 0.031 \\
\hline Labour productivity & $-0.191 * *$ & 0.085 \\
\hline TFP & $7.69 \mathrm{E}-10$ & $5.38 \mathrm{E}-10$ \\
\hline Age & 0.095 & 0.121 \\
\hline Export intensity & 0.016 & 0.054 \\
\hline Indebtedness rate & $0.148 * * *$ & 0.052 \\
\hline Number of observations & \multicolumn{2}{|c|}{217} \\
\hline
\end{tabular}

Note: *,** and *** mark statistical significance levels of $10 \%, 5 \%$ and $1 \%$ respectively. Statistical significance was determined by means of a bootstrapping procedure with 500 repetitions.

Source: Authors'own calculation based on data by the Ministry of Finance, Financial Agency and Court Registry. 